\title{
Bur open A population-based case-control study on social factors and risk of testicular germ cell tumours
}

\author{
Nils Schmeisser, ${ }^{1,2}$ David I Conway, ${ }^{3}$ Andreas Stang, ${ }^{4}$ Ingeborg Jahn, ${ }^{5}$ \\ Christa Stegmaier, ${ }^{6}$ Cornelia Baumgardt-Elms, ${ }^{7}$ Karl-Heinz Jöckel, ${ }^{8}$ \\ Thomas Behrens, ${ }^{9}$ Wolfgang Ahrens ${ }^{2,9}$
}

To cite: Schmeisser N, Conway DI, Stang A, et al. A population-based casecontrol study on social factors and risk of testicular germ cell tumours. BMJ Open 2013;3:e003833. doi:10.1136/bmjopen-2013003833

- Prepublication history for this paper is available online. To view these files please visit the journal online (http://dx.doi.org/10.1136/ bmjopen-2013-003833).

Received 16 August 2013 Accepted 16 August 2013

For numbered affiliations see end of article.

Correspondence to Dr Wolfgang Ahrens; ahrens@bips.uni-bremen.de

\section{ABSTRACT}

Objectives: Incidence rates for testicular cancer have risen over the last few decades. Findings of an association between the risk of testicular cancer and social factors are controversial. The association of testicular cancer and different indicators of social factors were examined in this study.

Design: Case-control study.

Setting: Population-based multicentre study in four German regions (city states Bremen and Hamburg, the Saarland region and the city of Essen).

Participants: The study included 797 control participants and 266 participants newly diagnosed with testicular cancer of which 167 cases were classified as seminoma and 99 as non-seminoma. The age of study participants ranged from 15 to 69 years.

Methods: Social position was classified by educational attainment level, posteducational training, occupational sectors according to Erikson-GoldthorpePortocarrero (EGP) and the socioeconomic status (SES) on the basis of the International SocioEconomic Index of occupational status (ISEI). ORs and corresponding $95 \% \mathrm{Cls}(95 \% \mathrm{Cls})$ were calculated for the whole study sample and for seminoma and nonseminoma separately.

Results: Testicular cancer risk was modestly increased among participants with an apprenticeship (OR=1.7 (95\% $\mathrm{Cl} 1.0$ to 2.8$)$ ) or a university degree $(\mathrm{OR}=1.6(95 \% \mathrm{Cl} 0.9$ to 2.8$))$ relative to those whose education was limited to school. Analysis of occupational sectors revealed an excess risk for farmers and farm-related occupations. No clear trend was observed for the analyses according to the ISEIscale.

Conclusions: Social factors based on occupational measures were not a risk factor for testicular cancer in this study. The elevated risk in farmers and farmrelated occupations warrants further research including analysis of occupational exposures.

\section{INTRODUCTION}

The population affected most by testicular cancer are men between 15 and 40 years of

\section{ARTICLE SUMMARY}

Strengths and limitations of this study

- Occupational social factors were measured on the basis of a detailed lifetime history of occupations. This population-based study allows examination of the full spectrum of social differences in the general population.

- The basis for the classification of social position is relatively valid because job histories usually are reported with good accuracy and the information was obtained by in-person interviews.

- The differential response of cases $(76 \%)$ and controls $(57 \%)$ may bias the effect estimates if possible selection effects differ between both groups. Also periods of unemployment and illness cannot be ranked by the scales utilised in this study.

age. For men older than 40 years of age the risk of testicular cancer decreases continuously. ${ }^{1}{ }^{2}$ The age distribution of testicular cancer is in sharp contrast to other neoplasms for which incidence rises with increasing age. Established risk factors for testicular cancer include a family history of testicular cancer and a history of an undescended testis. ${ }^{3}{ }^{4}$ Exposure to endocrine disrupting chemicals in an occupational context or in utero, has been suggested as a factor in cancer development. ${ }^{5}$ The incidence rates of testicular cancer have risen continuously in Western Europe and other industrialised countries, which may be due to changed environmental and life circumstances in these countries. In particular, in Germany the average number of testicular cancer per year in the 1980s and 1990s were 3196 and 3836, respectively. The corresponding age-standardised incidence rates were 7.7 and $8.9 / 100000 .{ }^{6}$ However, study results on the association of social factors and testicular cancer have been conflicting. Excess risks for higher levels of education or occupations 
related to higher social class, like administrators and managers and other professionals were observed in some studies. ${ }^{7-10}$ Other studies did not observe an association between social status and testicular cancer ${ }^{11-17}$ or even observed an inverse association. ${ }^{18}{ }^{19}$ In one study the association of testicular cancer and socioeconomic status (SES) differed by histological type. ${ }^{20} \mathrm{~A}$ register-based study in Finland observed a decrease of testicular cancer incidence rates among participants of higher social classes and an increase of incidence rates in the lower social classes between 1971 and 1995, leading to a levelling off of the social gradient. ${ }^{21}$

In this study, in addition to educational attainment at school and level of professional training as defined in a previous study ${ }^{22}$ further social factors based on job histories were considered. In detail, SES based on the International SocioEconomic Index (ISEI) ${ }^{23}$ and social class based on the Erikson-Goldthorpe-Portocarrero (EGP) ${ }^{24}$ classification was explored. The ISEI of occupation, which is a vertical grouping approach, as well as the EGP classification of occupations which adopts a class schema, claim that employment relations are basic social characteristics of a Western society.

\section{STUDY SUBJECTS AND METHODS}

All participants were registered residents of the city states Bremen and Hamburg, the Saarland region and the city of Essen. Study participants randomly drawn from registration offices had to live in the study regions between July 1995 and December 1997. Incident cases, diagnosed between July 1995 and December 1997, were reported by an active registration system through hospitals and pathologists. In Hamburg, cases were also identified through the state cancer registry. Eligible cases had to have a new diagnosis of tumour of the testis (ICD-10: C62.0-C62.9; ICD-O: M9060-M9102).

A total of 353 eligible cases and 2014 potential controls were contacted for this study. Among cases, 54 persons were not reached, 29 persons refused participation. One case was excluded due to insufficient German language skills. Participation was denied by 552 control subjects, 32 were excluded due to insufficient language skills, 512 had moved away, had died or were never reached.

Copies of pathology reports and histological material were obtained from hospitals. Pathology reports were reviewed centrally and compared with histological material when available by a reference pathologist to determine the histological type of tumour. Tumours were classified as seminomas $(\mathrm{N}=167,62.8 \%)$, including seminoma not other specified (ICD-O, M9061: $\mathrm{n}=160$ ), anaplastic seminoma (M9062: $\mathrm{n}=4)$ or non-seminomas $(\mathrm{N}=99,37.2 \%)$, including embryonal carcinoma (M9070: $\mathrm{n}=26$ ), yolk sac tumour (M9071: $\mathrm{n}=1$ ), malignant teratoma not other specified (M9080: $\mathrm{n}=2$ ), teratocarcinoma (M9081: $\mathrm{n}=15$ ), malignant teratoma, intermediate (M9083: $n=5)$, mixed germ cell tumour (M9085: $\mathrm{n}=49$ ) and choriocarcinoma
(M9100: $\mathrm{n}=1$ ) according to Parkin et al. ${ }^{25}$ More detailed descriptions and demographic characteristics of the participants were published elsewhere. ${ }^{22}{ }^{26-28}$ Cases and controls had to be between 15 and 69 years of age. A n: m-group-matching the 5-year age strata and study region was chosen. To obtain sufficient power in this study, a matching ratio of $1: 4$ was realised for the age group 3569 , while for the age strata $15-34$ a matching ratio of $1: 2$ was considered to be sufficient since most cases were expected in this age group. Owing to the overlap of the age distribution of seminoma and non-seminoma cases, the majority of controls matched to both seminoma and non-seminoma cases. Thus, for the analyses by the histological subgroup, 725 controls were matched by age and region to the seminoma cases while 682 controls were matched by age and region to the non-seminoma cases. Inclusion criteria were fulfilled by 266 cases and 918 controls. Cases and controls were recruited in parallel. For this purpose, controls were selected prospectively according to the expected case distribution. This left 121 controls for which no matching case interview was obtained.

Participants were interviewed face-to-face $(\mathrm{N}=984$, $92.3 \%)$ or by telephone $(\mathrm{N}=82,7.7 \%)$. Almost all interviews were performed with an index person $(\mathrm{N}=978$, $91.7 \%)$. For deceased participants or participants too ill to answer the questions, a next-of-kin interview was solicited. The interview entailed questions about familial characteristics, family history of cancer and other diseases, medical conditions since childhood, chemical and physical exposures and an occupational biography for every job held 6 months or longer.

For each employment period, the job title and industry and a brief summary of the job tasks were assessed. Each job was assigned a five-digit International Standard Code of Occupations (ISCO) ${ }^{29}$ and a five-digit industry code (NACE). ${ }^{30}$

\section{Assessment of social factors}

Measures of social factors in this study were level of educational attainment at school, level of professional training, occupational sector based on EGP and social status based on ISEI.

Job title codes (ISCO) were linked to the ISEI of Occupational Status.$^{23}$ The ISEI assigns values between 10 and 90 to job titles with respect to education and income. Judges, lawyers and physicians achieve the highest values, while unskilled labourers in agriculture and housekeepers the lowest values. In this scale, a continuous hierarchicy approaches the distinctions of workrelated tasks and social patterns disappear in favour of a single parameter. The ISEI score ranks occupations by level of education as well as income. ${ }^{23}$ ISEI scores were defined for the maximum score ever achieved and the longest held and the last job, respectively. ISEI scores were grouped into five categories employing the best possible equal distribution of controls.

For the present analyses, ISCO codes were classified by occupational sector according to EGP. The EGP typology 
is based on occupational group, required training, selfsupport/independence, social mobility and leadership. Within a category it assumes social homogeneity in terms of the market situation (sources and levels of income, degree of economic security and chances of economic advancement) and in terms of the work situation (autonomy in performing work-tasks and roles) (24). Each reported job was classified into one of the following 10 occupational categories: (I) higher service (includes mostly professionals, large enterprise employers and higher managers ( $>10$ subordinates) $)$; (II) lower service (includes mostly associate professionals, lower managers (1-10 subordinates), higher sales); (III) routine clericals/sales (includes non-manual administration and sales workers); (IV) small employers (includes small entrepreneurs (1-10 subordinates); (V) selfemployed (own account workers, no employees, artists); (VI) manual foremen (manual workers with supervisory status ( $>1$ subordinate)); (VII) skilled manual (mostly craft workers, some skilled service, skilled machine operators, also gardeners); (VIII) semi-unskilled manual (mostly machine operators, elementary sales services and state work creation scheme); (IX) farm workers (employed farm workers, irrespective of skill level; also family farm workers); (X) farmers/farm managers (selfemployed and supervisory farm workers, irrespective of skill level). Categories were collapsed into five groups (I and II; III-V; VI and VII; VII; IX and X) for analysis.

Occupational histories excluded jobs starting within 1 year before diagnosis in cases or before the first mailing to controls. The highest category served as the reference for the analysis of first job, last job, longest held job, job ranked highest and job ranked lowest. Participants who had never worked were excluded, except for the ever/never analysis of EGP. All participants who did not belong to the group under consideration were used as the reference group in the ever/ never analysis.

Educational level was classified by years of schooling into four levels according to the German school system ( $\leq 9$ years (no school degree, Sonderschulabschluss, Hauptschulabschluss), 10 years (mittlere Reife), 12 years (Fachabitur) and 13 years (Abitur)). In addition, the highest professional level attained after school (none, apprenticeship, university or college degree, others) was analysed.

\section{Statistical analysis}

OR and $95 \%$ CIs (95\% CI) were calculated stratified for the 5-year age strata and study centres. All analyses were carried out for the whole study group and stratified by histological subgroups. Controls were excluded from the subgroup analyses if no matching case was available in an age-group $\times$ study region stratum. ORs and corresponding CIs were estimated by conditional logistic regression using the procedure PHREG. The level of statistical significance was defined as $\mathrm{p}<0.05$ (2-sided). The study was designed as an exploratory study as the risk factors of testicular cancer are largely unknown. The study was powered to detect an OR of 1.8 for any risk factor with a prevalence of $20 \%$, and an OR of 2.0 for any risk factor with a prevalence of $10 \%$. The study was not powered to confirm any risk for seminoma and nonseminoma cases separately. All analyses were carried out using SAS 8.2. ORs were not reported if a given category included less than three cases.

\section{RESULTS}

The proportion of medically confirmed cryptorchidism was higher in cases $(9.9 \%)$ than in controls $(3.6 \%)$. Overall, non-seminoma cases were on average 5 years younger than seminoma cases and controls (nonseminoma: 30 (21-41); seminoma: 35 (28-49); controls: 35 (26-58) (median (10th -90th rcentile))).

The distribution of number of occupations for cases and controls is shown in table 1 . Seven cases (6 nonseminoma cases; 1 seminoma case) and 20 controls were still attending school or were students with no job history at the time of diagnosis (case) or first mailing (controls). Job histories of non-seminoma cases lasted 13 (4-25) years, of seminoma cases 19 (8-32) and of controls 18 (6-41) years (median (10th-90th centile)). Except for the non-seminoma cases the number of occupational periods did not differ substantially between cases and controls.

The distribution of cases and controls by educational level and professional degree is shown in table 2. Participants with professional degrees (ie, apprenticeship, technical colleges, study at university and university for applied sciences) were at a higher risk as compared to participants without professional training in the

Table 1 Frequency of economically active periods for cases and controls for whole study sample and for seminoma and non-seminoma

\begin{tabular}{lrrrr}
$\begin{array}{l}\text { Study group/ } \\
\text { number of job } \\
\text { periods }\end{array}$ & $\begin{array}{l}\text { Number } \\
\text { of cases }\end{array}$ & $\begin{array}{l}\text { Per } \\
\text { cent }\end{array}$ & $\begin{array}{l}\text { Number } \\
\text { of } \\
\text { controls }\end{array}$ & $\begin{array}{c}\text { Per } \\
\text { cent }\end{array}$ \\
\hline $\begin{array}{l}\text { Complete study } \\
\text { sample }\end{array}$ & 266 & 100.0 & 797 & 100.0 \\
0 & & & & \\
$1-2$ & 7 & 2.6 & 20 & 2.5 \\
3-4 & 79 & 29.7 & 213 & 26.7 \\
5+ & 112 & 42.1 & 321 & 40.3 \\
Seminoma & 68 & 25.6 & 243 & 30.5 \\
0 & 167 & 100.0 & 725 & 100.0 \\
$1-2$ & 1 & 0.6 & 13 & 1.8 \\
3-4 & 42 & 25.2 & 192 & 26.5 \\
5+ & 72 & 43.1 & 299 & 41.2 \\
Non-seminoma & 52 & 31.1 & 221 & 30.5 \\
0 & 99 & 100.0 & 682 & 100.0 \\
1-2 & 6 & 6.1 & 20 & 2.9 \\
3-4 & 37 & 37.4 & 193 & 28.3 \\
5+ & 40 & 40.4 & 274 & 40.2 \\
\hline
\end{tabular}


Table 2 Distribution of cases and controls by educational level and professional degrees and corresponding ORs with 95\% Cls

\begin{tabular}{|c|c|c|c|c|c|}
\hline & \multicolumn{2}{|c|}{ Cases } & \multicolumn{2}{|c|}{ Controls } & \multirow[b]{2}{*}{ OR $(95 \% \mathrm{Cl})$} \\
\hline & $\overline{\mathbf{N}}$ & Per cent & $\overline{\mathbf{N}}$ & Per cent & \\
\hline Complete study sample & 269 & 100.0 & 797 & 100.0 & \\
\hline \multicolumn{6}{|l|}{ Years at school } \\
\hline$\leq 9$ & 89 & 33.1 & 304 & 38.1 & $1.0^{*}$ \\
\hline 10 & 61 & 22.7 & 192 & 24.1 & 0.9 (0.6 to 1.3$)$ \\
\hline 12 & 25 & 9.3 & 78 & 9.8 & $0.9(0.5$ to 1.5$)$ \\
\hline 13 & 9 & 34.9 & 222 & 27.9 & 1.1 (0.8 to 1.6$)$ \\
\hline Unknown & 0 & 0.0 & 1 & 0.1 & - \\
\hline \multicolumn{6}{|l|}{ Professional training } \\
\hline None & 22 & 8.3 & 95 & 11.9 & $1.0^{*}$ \\
\hline Apprenticeship & 163 & 61.3 & 485 & 60.9 & 1.7 (1.0 to 2.8$)$ \\
\hline University degree & 62 & 23.3 & 154 & 19.3 & $1.6(0.9$ to 2.8$)$ \\
\hline Other & 19 & 7.1 & 63 & 7.9 & 1.0 (0.4 to 2.3$)$ \\
\hline Seminoma & 170 & 100.0 & 725 & 100.0 & \\
\hline \multicolumn{6}{|l|}{ Years at school } \\
\hline$\leq 9$ & 57 & 35.3 & 267 & 36.8 & $1.0^{*}$ \\
\hline 10 & 39 & 22.9 & 180 & 24.8 & $0.9(0.6$ to 1.4$)$ \\
\hline 12 & 17 & 10.0 & 75 & 10.3 & $0.9(0.5$ to 1.7$)$ \\
\hline 13 & 54 & 31.8 & 202 & 27.9 & $1.0(0.7$ to 1.7$)$ \\
\hline Unknown & 0 & 0.0 & 1 & 0.1 & - $\quad-$ \\
\hline \multicolumn{6}{|l|}{ Professional training } \\
\hline None & 10 & 7.1 & 88 & 12.1 & $1.0^{*}$ \\
\hline Apprenticeship & 110 & 65.3 & 446 & 61.5 & $2.5(1.3$ to 5.1$)$ \\
\hline University degree & 40 & 23.5 & 142 & 19.6 & 2.1 (1.0 to 4.6$)$ \\
\hline Other & 7 & 4.1 & 49 & 6.8 & 2.3 (0.7 to 7.2$)$ \\
\hline Non-seminoma & 99 & 100.0 & 682 & 100.0 & \\
\hline \multicolumn{6}{|l|}{ Years at school } \\
\hline$\leq 9$ & 29 & 29.3 & 225 & 33.2 & $1.0^{*}$ \\
\hline 10 & 22 & 22.2 & 172 & 25.4 & $0.8(0.4$ to 1.5$)$ \\
\hline 12 & 8 & 8.1 & 73 & 10.8 & 0.8 (0.3 to 1.9$)$ \\
\hline 13 & 40 & 40.4 & 206 & 30.4 & $1.1(0.6$ to 1.9$)$ \\
\hline Unknown & 0 & 0.0 & 1 & 0.1 & - \\
\hline \multicolumn{6}{|l|}{ Professional training } \\
\hline None & 12 & 12.1 & 80 & 11.7 & $1.0^{*}$ \\
\hline Apprenticeship & 53 & 53.5 & 400 & 58.7 & $0.9(0.5$ to 1.9$)$ \\
\hline University degree & 22 & 22.2 & 140 & 20.5 & $1.1(0.5$ to 2.5$)$ \\
\hline Other & 12 & 12.1 & 62 & 9.1 & $0.5(0.2$ to 1.4$)$ \\
\hline
\end{tabular}

${ }^{\star}$ Reference.

whole study group and in the seminoma subgroup but not in the non-seminoma subgroup. No risk was observed for being employed before the age of 18 (OR=1.0; 95\% CI 0.7 to 1.3 ) (data not shown).

No difference in the average ISEI score was observed between cases and controls (cases: mean score 42.5, median score 39; controls: mean score 42.4, median score 39). Risk estimates by ISEI scores are presented in table 3. Analyses of the maximum ISEI score reached during lifetime showed no increased risks, neither for the complete study sample, nor for the seminoma and non-seminoma study samples. Similarly, the analyses by ISEI of the job held the longest and the last job held revealed no associations with testicular cancer.

ORs by EGP categories are shown in table 4. An increased risk for testicular cancer was observed for ever holding an agriculture-related job (OR=1.9 95\% CI 1.0 to 3.8). For seminoma cases the effect was of the same strength ( $\mathrm{OR}=2.195 \%$ CI 1.0 to 4.5), while for nonseminoma cases the OR estimate was smaller and statistically non-significant ( $\mathrm{OR}=1.695 \%$ CI 0.5 to 4.8$)$. For all other classes no increased risk was observed. This pattern is seen for almost all analyses presented in table 4 . Compared to participants in the highest EGP category, increased risks were observed for category IX-X for the first, the last and the occupation with the highest EGP category ever.

\section{DISCUSSION}

Different methods of assigning social position may produce different results in terms of trends in health 
Table 3 Distribution of achieved maximum International SocioEconomic Index (ISEI) score and of ISEI scores for the longest and last held job for whole study population and for histological subgroups with corresponding ORs

\begin{tabular}{|c|c|c|c|c|c|}
\hline \multirow[b]{2}{*}{ ISEI Score } & \multicolumn{2}{|c|}{ Cases } & \multicolumn{2}{|c|}{ Controls } & \multirow[b]{2}{*}{ OR (95\% Cl) } \\
\hline & $\overline{\mathbf{N}}$ & Per cent & $\overline{\mathbf{N}}$ & Per cent & \\
\hline \multicolumn{6}{|c|}{ Complete study sample } \\
\hline \multicolumn{6}{|c|}{ Maximum ISEI score } \\
\hline$(16-37)$ & 5 & 22.0 & 156 & 19.6 & $1.1(0.7$ to 1.7$)$ \\
\hline$(37-44)$ & 47 & 18.1 & 172 & 21.6 & 0.8 (0.5 to 1.3$)$ \\
\hline$(44-55)$ & 51 & 19.7 & 151 & 19.0 & $1.0(0.6$ to 1.5$)$ \\
\hline$(55-66)$ & 51 & 19.7 & 151 & 19.0 & $0.9(0.6$ to 1.5$)$ \\
\hline$(66-88)$ & 53 & 20.5 & 147 & 18.4 & $1^{*}$ \\
\hline Missing & 7 & & 20 & & \\
\hline \multicolumn{6}{|c|}{ Last held job } \\
\hline$(16-37)$ & 95 & 36.7 & 266 & 34.2 & $0.9(0.6$ to 1.4$)$ \\
\hline$(37-44)$ & 35 & 13.5 & 131 & 16.8 & $0.8(0.5$ to 1.3$)$ \\
\hline$(44-55)$ & 38 & 14.7 & 145 & 18.6 & 0.7 (0.4 to 1.1$)$ \\
\hline$(55-66)$ & 44 & 17.0 & 117 & 15.0 & $0.9(0.5$ to 1.5$)$ \\
\hline$(66-88)$ & 47 & 18.1 & 119 & 15.3 & $1^{*}$ \\
\hline Missing & 7 & & 20 & & \\
\hline \multicolumn{6}{|c|}{ Longest held job } \\
\hline$(16-37)$ & 102 & 39.4 & 277 & 34.9 & $0.9(0.6$ to 1.4$)$ \\
\hline$(37-44)$ & 40 & 15.4 & 150 & 18.8 & 0.8 (0.4 to 1.3$)$ \\
\hline$(44-55)$ & 33 & 12.7 & 144 & 18.1 & 0.6 (0.3 to 1.0$)$ \\
\hline$(55-66)$ & 43 & 16.6 & 106 & 13.3 & $1.0(0.6$ to 1.6$)$ \\
\hline$(66-88)$ & 41 & 15.8 & 100 & 12.6 & $1^{*}$ \\
\hline Missing & 7 & & 20 & 2.4 & \\
\hline \multicolumn{6}{|l|}{ Seminoma } \\
\hline \multicolumn{6}{|c|}{ Maximum ISEI score } \\
\hline$(16-37)$ & 34 & 20.5 & 141 & 19.9 & $1.2(0.7$ to 2.2$)$ \\
\hline$(37-44)$ & 32 & 19.3 & 159 & 22.3 & 0.9 (0.5 to 1.5$)$ \\
\hline$(44-55)$ & 32 & 19.3 & 137 & 19.2 & 0.9 (0.5 to 1.6$)$ \\
\hline$(55-66)$ & 32 & 19.3 & 141 & 19.8 & $0.9(0.5$ to 1.6$)$ \\
\hline$(66-88)$ & 36 & 21.7 & 134 & 18.8 & $1^{*}$ \\
\hline Missing & 1 & & 13 & & \\
\hline \multicolumn{6}{|l|}{ Last held job } \\
\hline$(16-37)$ & 56 & 33.7 & 241 & 33.8 & $0.9(0.5$ to 1.5$)$ \\
\hline$(37-44)$ & 24 & 14.5 & 123 & 17.3 & 0.8 (0.5 to 1.5$)$ \\
\hline$(44-55)$ & 25 & 15.1 & 133 & 18.7 & 0.7 (0.4 to 1.3$)$ \\
\hline$(55-66)$ & 29 & 17.5 & 109 & 15.3 & $0.9(0.5$ to 1.6$)$ \\
\hline$(66-88)$ & 32 & 19.3 & 107 & 15.0 & $1^{*}$ \\
\hline \multicolumn{6}{|c|}{ Longest held job } \\
\hline$(16-37)$ & 61 & 36.7 & 259 & 35.9 & 0.8 (0.5 to 1.4$)$ \\
\hline$(37-44)$ & 29 & 17.5 & 133 & 18.3 & 0.8 (0.5 to 1.5$)$ \\
\hline$(44-55)$ & 21 & 12.7 & 128 & 17.7 & 0.5 (0.3 to 1.0$)$ \\
\hline$(55-66)$ & 25 & 15.1 & 101 & 13.9 & $0.8(0.4$ to 1.5$)$ \\
\hline$(66-88)$ & 30 & 18.1 & 91 & 12.6 & $1^{*}$ \\
\hline Missing & 1 & & 13 & & \\
\hline \multicolumn{6}{|c|}{ Non-seminoma } \\
\hline \multicolumn{6}{|c|}{ Maximum ISEI score } \\
\hline$(16-37)$ & 22 & 23.7 & 128 & 19.5 & 0.9 (0.4 to 1.9$)$ \\
\hline$(37-44)$ & 16 & 17.2 & 148 & 22.3 & 0.7 (0.3 to 1.5$)$ \\
\hline$(44-55)$ & 19 & 20.4 & 129 & 19.5 & 0.9 (0.5 to 1.9$)$ \\
\hline$(55-66)$ & 19 & 20.4 & 133 & 20.1 & $1.0(0.5$ to 1.9$)$ \\
\hline$(66-88)$ & 17 & 18.3 & 124 & 18.7 & $1^{*}$ \\
\hline Missing & 6 & & & & \\
\hline \multicolumn{6}{|l|}{ Last held job } \\
\hline$(16-37)$ & 37 & 39.8 & 223 & 33.8 & $0.9(0.4$ to 1.7$)$ \\
\hline$(37-44)$ & 12 & 14.0 & 110 & 16.6 & 0.7 (0.3 to 1.6$)$ \\
\hline$(44-55)$ & 14 & 14.0 & 126 & 19.0 & 0.7 (0.3 to 1.5$)$ \\
\hline$(55-66)$ & 15 & 16.1 & 103 & 15.5 & $0.9(0.4$ to 2.0$)$ \\
\hline
\end{tabular}


Table 3 Continued

\begin{tabular}{|c|c|c|c|c|c|}
\hline \multirow[b]{2}{*}{ ISEI Score } & \multicolumn{2}{|c|}{ Cases } & \multicolumn{2}{|c|}{ Controls } & \multirow[b]{2}{*}{ OR (95\% Cl) } \\
\hline & $\overline{\mathbf{N}}$ & Per cent & $\overline{\mathbf{N}}$ & Per cent & \\
\hline$(66-88)$ & 15 & 16.1 & 100 & 15.1 & $1^{*}$ \\
\hline \multicolumn{6}{|c|}{ Longest held job } \\
\hline$(16-37)$ & 40 & 40.4 & 230 & 33.9 & 1.1 (0.5 to 2.2$)$ \\
\hline$(37-44)$ & 12 & 12.1 & 130 & 19.1 & 0.7 (0.3 to 1.7$)$ \\
\hline$(44-55)$ & 12 & 12.1 & 128 & 18.8 & $0.6(0.3$ to 1.5$)$ \\
\hline$(55-66)$ & 18 & 18.2 & 91 & 13.3 & $1.4(0.6$ to 3.3$)$ \\
\hline$(66-88)$ & 11 & 11.1 & 83 & 12.2 & $1^{*}$ \\
\hline Missing & 6 & 6.1 & 19 & 2.8 & \\
\hline
\end{tabular}

and inequality. ${ }^{31} 32$ Four indicators of social position were analysed in this study. School education was not associated with testicular cancer risk. The elevated risk observed for professional training against no training was restricted to the seminoma subgroup. Overall, our data provide no evidence that the examined social dimensions are associated with testicular cancer. This result is in line with other studies. ${ }^{11} 17$

Elevated risks for EGP categories other than agriculture were not observed in this study. An excess risk in agriculture and related occupations have been observed in several previous studies. ${ }^{9} 33-35$ It has been suggested that the observed risks in agriculture and related-occupations could be associated with specific exposures such as pesticides, ${ }^{33} 35$ fertilisers ${ }^{36} 37$ or contact with farm animals and zoonotic infections ${ }^{33}$ which were not in the scope of this analysis. The absence of increased risks for non-agricultural occupational sectors based on the EGP corroborates previous studies. $^{142138}$

Social status based on ISEI was no risk factor for testicular cancer in this study. If a social gradient for testicular cancer in Germany existed in the past and exposures were associated with this gradient, this gradient may have been attenuated by an increase in exposures that do not differ by social position or for which the social gradient declined over time. The rising trends of testicular cancer in industrialised countries might be an indirect indication for such an increase of exposures that are (or have become) independent of social position.

This study has some limitations. First, the study suffered from only modest response among controls (cases $76 \%$, controls $57 \%$ ). In particular, in the study region of Hamburg participation was lower among controls with lower education which might have resulted in an overestimation of the risk in the lower social status groups. Hence, it is possible that a participation bias might have biased the effect estimates. However, a sensitivity analysis excluding Hamburg revealed similar findings.

Second, some non-differential misclassification of social status is likely to have occurred. As the assessment of social status is not based on a dichotomous variable, the direction of bias due to non-differential misclassification cannot be predicted. However, our classification is based on occupational titles which are known to be reported with good validity. Moreover, the fact that different indicators of social position give similar results increases confidence in our findings.

Third, periods of unemployment and illness cannot be ranked by both scales utilised in this study. Non-consideration of such periods may lead to an underestimation of any social difference. ${ }^{39}$

The strength of this study is to measure occupational social factors on the basis of a complete history of occupations. This information was obtained by in-person interviews. The population-based design of this study allows full examination of social differences. Study participants were not aware of this study hypothesis, and occupational biography is an unprejudiced variable, so reporting bias is unlikely to occur. Different possible confounding variables were considered by adjusting for posteducational degree or medically confirmed undescended testis and job frequency but the results remained stable in all analyses.

\section{CONCLUSION}

The absence of an effect was not specific to the ISEI score, as another occupational scaling method, the EGP typology, showed no associations with testicular cancer, except for farming and farm-related jobs. Different social indicators may mean different things with regard to correlates of social position. Our data indicate that a simple social gradient of testicular cancer risk-if it had existed in the past-may no longer exist. Rather, our findings support the hypothesis that social inequalities in testicular cancer are not related to occupation-based social position. More information is needed on the specific social correlates (eg, work characteristics, living areas). It should be noted that education and occupation are not only indicators of access to material properties, but are also related to psychosocial properties.

\section{Author affiliations}

${ }^{1}$ State Statistical Institute Bremen, Bremen, Germany

${ }^{2}$ University of Bremen, Bremen, Germany

${ }^{3}$ University of Glasgow, College of Medical, Veterinary and Life Sciences, Glasgow, UK 
Table 4 Distribution of study participants and corresponding ORs with $95 \% \mathrm{Cl}$ by occupational sectors according to Erikson, Goldthorpe and Portocarrero for complete study group and histological subgroups

\begin{tabular}{|c|c|c|c|c|c|c|c|c|c|c|c|c|c|c|c|}
\hline \multirow[b]{3}{*}{ Category* } & \multicolumn{4}{|c|}{ Complete study sample } & & \multicolumn{4}{|c|}{ Seminoma } & & \multicolumn{4}{|c|}{ Non-seminoma } & \\
\hline & \multirow[b]{2}{*}{$\mathbf{N}$} & \multicolumn{2}{|l|}{ Cases } & \multicolumn{2}{|l|}{ Controls } & \multirow[b]{2}{*}{$\mathbf{N}$} & \multicolumn{2}{|l|}{ Cases } & \multicolumn{2}{|l|}{ Controls } & \multirow[b]{2}{*}{$\mathbf{N}$} & \multicolumn{2}{|l|}{ Cases } & \multicolumn{2}{|l|}{ Controls } \\
\hline & & Per cent & $\mathbf{N}$ & Per cent & OR (95\% Cl) & & Per cent & $\mathbf{N}$ & Per cent & OR $(95 \% \mathrm{Cl})$ & & Per cent & $\mathbf{N}$ & Per cent & OR $(95 \% \mathrm{Cl})$ \\
\hline \multicolumn{16}{|c|}{ First held job } \\
\hline I-II & 25 & 9.5 & 69 & 8.9 & 1 & 15 & 8.9 & 63 & 8.8 & 1 & 10 & 10.8 & 60 & 9.1 & 1 \\
\hline III-V & 40 & 15.3 & 140 & 18.0 & $0.9(0.5$ to 1.5$)$ & 24 & 14.2 & 126 & 17.7 & $0.9(0.4$ to 1.8$)$ & 16 & 17.2 & 126 & 19.1 & $0.8(0.3$ to 1.9$)$ \\
\hline VI-VII & 132 & 49.6 & 404 & 52.0 & $1.1(0.8$ to 1.5$)$ & 88 & 52.7 & 372 & 52.2 & $1.2(0.8$ to 1.7$)$ & 44 & 47.3 & 335 & 50.8 & $0.9(0.4$ to 1.9$)$ \\
\hline VIII & 55 & 21.4 & 148 & 19.0 & $1.1(0.8$ to 1.4$)$ & 33 & 20.1 & 138 & 19.4 & $1.1(0.8$ to 1.6$)$ & 22 & 23.7 & 128 & 19.4 & $1.0(0.6$ to 1.5$)$ \\
\hline$I X-X$ & 7 & 2.7 & 16 & 2.1 & $1.6(0.5$ to 4.6$)$ & 6 & 3.6 & 13 & 1.8 & 2.1 (0.6 to 6.7$)$ & 1 & 1.1 & 11 & 1.7 & - \\
\hline \multicolumn{16}{|c|}{ Last held job } \\
\hline I-II & 70 & 26.7 & 172 & 22.1 & 1 & 45 & 26.6 & 155 & 21.8 & 1 & 25 & 26.9 & 150 & 22.7 & 1 \\
\hline III-V & 533 & 20.2 & 192 & 24.7 & 0.7 (0.4 to 1.0$)$ & 34 & 20.1 & 180 & 25.3 & 0.7 (0.4 to 1.2$)$ & 19 & 20.4 & 162 & 24.5 & $0.6(0.3$ to 1.1$)$ \\
\hline VI-VII & 81 & 30.5 & 243 & 31.3 & 0.9 (0.6 to 1.3$)$ & 54 & 32.3 & 223 & 31.3 & $1.0(0.6$ to 1.6$)$ & 27 & 29.0 & 205 & 31.1 & 0.7 (0.4 to 1.3$)$ \\
\hline VIII & 50 & 19.8 & 165 & 21.2 & 0.9 (0.7 to 1.1$)$ & 29 & 18.3 & 151 & 21.2 & 0.9 (0.7 to 1.2$)$ & 21 & 22.6 & 138 & 20.9 & $0.9(0.6$ to 1.2$)$ \\
\hline IX-X & 5 & 1.9 & 5 & 0.6 & 3.0 (0.8 to 11.7$)$ & 4 & 2.4 & 3 & 0.4 & 4.3 (0.9 to 20.8 ) & 1 & 1.1 & 5 & 0.8 & - \\
\hline \multicolumn{16}{|c|}{ Longest held job } \\
\hline I-II & 54 & 20.6 & 145 & 18.7 & 1 & 37 & 21.9 & 133 & 18.7 & 1 & 17 & 18.3 & 125 & 18.9 & 1 \\
\hline III-V & 46 & 17.6 & 166 & 21.4 & 0.8 (0.5 to 1.2$)$ & 27 & 16.0 & 154 & 21.6 & 0.7 (0.4 to 1.2$)$ & 19 & 20.4 & 139 & 21.1 & $0.8(0.4$ to 1.6$)$ \\
\hline VI-VII & 100 & 38.6 & 287 & 36.9 & 1.1 (0.8 to 1.6$)$ & 69 & 41.3 & 261 & 36.7 & 1.2 (0.8 to 2.0$)$ & 31 & 33.3 & 242 & 36.7 & $0.8(0.4$ to 1.5$)$ \\
\hline VIII & 54 & 23.9 & 171 & 22.0 & 0.9 (0.6 to 1.3$)$ & 30 & 18.0 & 156 & 21.9 & $0.0(0.5$ to 1.2$)$ & 24 & 25.8 & 146 & 22.1 & $1.0(0.7$ to 1.4$)$ \\
\hline$I X-X$ & 5 & 1.9 & 8 & 1.0 & $1.3(0.4$ to 4.1$)$ & 3 & 1.8 & 8 & 1.1 & $1.0(0.2$ to 4.1$)$ & 2 & 2.2 & 8 & 1.2 & - \\
\hline \multicolumn{16}{|c|}{ Ever held job } \\
\hline I-II & 86 & 32.0 & 231 & 29.0 & $1.1(0.8$ to 1.5$)$ & 58 & 34.1 & 211 & 29.1 & $1.1(0.7$ to 1.5$)$ & 28 & 28.3 & 201 & 29.5 & $1.2(0.7$ to 1.9$)$ \\
\hline III-V & 92 & 34.2 & 308 & 38.6 & $0.7(0.5$ to 1.0$)$ & 58 & 34.1 & 286 & 39.4 & 0.6 (0.4 to 0.9$)$ & 34 & 34.3 & 268 & 39.3 & $0.9(0.5$ to 1.4$)$ \\
\hline VI-VII & 164 & 61.7 & 494 & 62.0 & $1.2(0.9$ to 1.6$)$ & 108 & 64.7 & 453 & 62.5 & $1.2(0.8$ to 1.7$)$ & 56 & 56.6 & 413 & 60.6 & $1.1(0.7$ to 1.7$)$ \\
\hline VIII & 128 & 48.1 & 392 & 49.2 & $1.0(0.7$ to 1.3$)$ & 84 & 50.3 & 362 & 49.9 & $1.0(0.7$ to 1.4$)$ & 44 & 44.4 & 333 & 48.8 & $1.0(0.6$ to 1.5$)$ \\
\hline IX-X & 16 & 6.0 & 30 & 3.8 & 1.9 (1.0 to 3.8$)$ & 12 & 7.2 & 23 & 3.2 & 2.1 (1.0 to 4.5$)$ & 4 & 4.0 & 22 & 3.2 & $1.6(0.5$ to 4.8$)$ \\
\hline
\end{tabular}

${ }^{*}$ Categories were assigned as follows: I=higher service (includes mostly professionals, large enterprise employers and higher managers ( $>10$ subordinates)); II=lower service (includes mostly associate professionals, lower managers (1-10 subordinates), higher sales); III=routine clerical/sales (includes routine clerical and sales workers); IV=small employers (includes small

entrepreneurs (1-10 subordinates); V=independent (own account workers, no employees, artists); $\mathrm{VI}=$ manual foremen (manual workers with supervisory status ( $>1$ subordinate)); $\mathrm{VII}=$ skilled

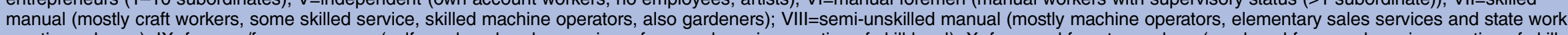

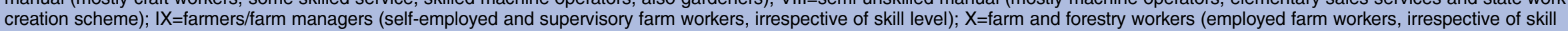
level; also family farm workers). 
${ }^{4}$ Medical Faculty, Clinical Epidemiology Unit, Martin-Luther-University of Halle-Wittenberg, Institute of Medical Epidemiology, Biometry and Informatics, Halle, Germany

${ }^{5}$ Department of Prevention and Evaluation, Leibniz-Institute for Prevention Research and Epidemiology-BIPS, Bremen, Germany

${ }^{6}$ Saarland Cancer Registry, Saarbrücken, Germany

${ }^{7}$ Authority of Science and Health, Authority for Social Affairs, Family, Health and Consumer Protection, Hamburg, Germany

${ }^{8}$ University of Duisburg-Essen, Institute for Medical Informatics, Biometry and Epidemiology, Essen, Germany

${ }^{9}$ Department of Epidemiological Methods and Etiologic Research, LeibnizInstitute for Prevention Research and Epidemiology_-BIPS, Bremen, Germany

Contributors NS performed the analysis, drafted the manuscript and interpreted the data. WA designed the study. DIC, AS, K-HJ and WA contributed substantially to the conception of the manuscript and/or the interpretation of the data. All authors contributed to the revision and finally approved the version to be published.

Funding Federal Ministry for Education and Research (BMBF no. 01HP 684/8). Competing interests None.

Ethics approval Ethical Committee of the University of Bremen.

Provenance and peer review Not commissioned; externally peer reviewed.

Data sharing statement No additional data are available.

Open Access This is an Open Access article distributed in accordance with the Creative Commons Attribution Non Commercial (CC BY-NC 3.0) license, which permits others to distribute, remix, adapt, build upon this work noncommercially, and license their derivative works on different terms, provided the original work is properly cited and the use is non-commercial. See: http:// creativecommons.org/licenses/by-nc/3.0/

\section{REFERENCES}

1. Bergström R, Adami HO, Möhner M, et al. Increase in testicular cancer incidence in six European countries: a birth cohort phenomenon. J Natl Cancer Inst 1996;88:727-33.

2. Liu S, Semenciw R, Waters $C$, et al. Clues to the aetiological heterogeneity of testicular seminomas and non-seminomas: time trends and age-period-cohort effects. Int $J$ Epidemiol 2000:29:826-31.

3. Pottern LM, Brown LM, Hoover RN, et al. Testicular cancer risk among young men: role of cryptorchidism and inguinal hernia. $J$ Natl Cancer Inst 1985;74:377-81.

4. Stang A, Ahrens W, Bromen K, et al. Undescended testis and the risk of testicular cancer: importance of source and classification of exposure information. Int J Epidemiol 2001;30:1050-6.

5. Schottenfeld D. Testicular cancer. In: Schottenfeld D, Fraumeni JF. eds Cancer epidemiology and prevention. New York: Oxford University Press, 1996:1205-19.

6. Krebsneuerkrankungen in Deutschland. 2010. http://www.rki.de

7. Rimpela AH, Pukkala El. Cancers of affluence: positive social class gradient and rising incidence trend in some cancer forms. Soc Sci Med 1987;24:601-6.

8. Prener A, Hsieh CC, Engholm G, et al. Birth order and risk of testicular cancer. Cancer Causes Control 1992;3:265-72.

9. Van den Eeden SK, Weiss NS, Strader $\mathrm{CH}$, et al. Occupation and the occurrence of testicular cancer. Am J Ind Med 1991;19:327-37.

10. Gallagher RP, Huchcroft S, Phillips N, et al. Physical activity, medical history, and risk of testicular cancer (Alberta and British Columbia, Canada). Cancer Causes Control 1995;6:398-406.

11. Brown LM, Pottern LM, Hoover RN. Testicular cancer in young men: the search for causes of the epidemic increase in the United States. $J$ Epidemiol Community Health 1987;41:349-54.

12. Davies TW, Palmer CR, Ruja E, et al. Adolescent milk, dairy product and fruit consumption and testicular cancer. $\mathrm{Br} J$ Cancer 1996;74:657-60.

13. Haughey BP, Graham S, Brasure J, et al. The epidemiology of testicular cancer in upstate New York. Am J Epidemiol 1989;130:25-36.

14. Marsa K, Johnsen NF, Bidstrup PE, et al. Social inequality and incidence of and survival from male genital cancer in a population-based study in Denmark, 1994-2003. Eur J Cancer 2008;44:2018-29.

15. Moller H, Skakkebaek NE. Risks of testicular cancer and cryptorchidism in relation to socio-economic status and related factors: case-control studies in Denmark. Int $J$ Cancer 1996;66:287-93.

16. Petridou E, Roukas $\mathrm{KI}$, Dessypris $\mathrm{N}$, et al. Baldness and other correlates of sex hormones in relation to testicular cancer. Int $J$ Cancer 1997;71:982-5.

17. United Kingdom Testicular Cancer Study Group. Aetiology of testicular cancer: association with congenital abnormalities, age at puberty, infertility, and exercise. United Kingdom Testicular Cancer Study Group. BMJ 1994;308:1393-9.

18. Dusek L, Abrahamova J, Lakomy R, et al. Multivariate analysis of risk factors for testicular cancer: a hospital-based case-control study in the Czech Republic. Neoplasma 2008;55:356-68.

19. Walschaerts M, Muller A, Auger J, et al. Environmental, occupationa and familial risks for testicular cancer: a hospital-based case-control study. Int J Androl 2007;30:222-9.

20. Hayes RB, Brown LM, Pottern LM, et al. Occupation and risk for testicular cancer: a case-control study. Int J Epidemiol 1990;19:825-31.

21. Pukkala E, Weiderpass E. Socioeconomic differences in incidence rates of cancers of the male genital organs in Finland, 1971-95. Int $J$ Cancer 2002;102:643-8.

22. Stang A, Ahrens W, Baumgardt-Elms C, et al. Adolescent milk fat and galactose consumption and testicular germ cell cancer. Cancer Epidemiol Biomarkers Prev 2006;15:2189-95.

23. Ganzeboom HBG, Degraaf PM, Treiman DJ, et al. A standard international socioeconomic index of occupational status. Soc Sci Res 1992;21:1-56.

24. Erikson R, Goldthorpe JH, Portocarero L. Intergenerational class mobility and the convergence thesis: England, France and Sweden. Br J Sociol 1983;34:303-43.

25. Parkin DM, Shanmugaratnam K, Sobin L, et al. Histological groups for comparative studies. Report 31. Lyon: International Agency for Research on Cancer, 1998.

26. Bromen K, Stang A, Baumgardt-Elms C, et al. Testicular, other genital, and breast cancers in first-degree relatives of testicular cancer patients and controls. Cancer Epidemiol Biomarkers Prev 2004;13:1316-24.

27. Stang $\mathrm{A}$, Jockel $\mathrm{KH}$, Baumgardt-Elms $\mathrm{C}$, et al. Firefighting and risk of testicular cancer: results from a German population-based case-control study. Am J Ind Med 2003;43:291-4.

28. Baumgardt-Elms C, Ahrens W, Bromen K, et al. Testicular cancer and electromagnetic fields (EMF) in the workplace: results of a population-based case-control study in Germany. Cancer Causes Control 2002;13:895-902.

29. International Labour Office. International Standard Classification of Occupations. ISCO68. Geneva: International Labour Office, 1968.

30. European Commission. National industrial classification of all economic activities (NACE). Luxembourg: Office for Official Publications of the EC, 1993.

31. Galobardes B, Shaw M, Lawlor DA, et al. Indicators of socioeconomic position (part 1). J Epidemiol Community Health 2006;60:7-12.

32. Galobardes B, Shaw M, Lawlor DA, et al. Indicators of socioeconomic position (part 2). J Epidemiol Community Health 2006;60:95-101.

33. Hardell L, Nasman A, Ohlson CG, et al. Case-control study on risk factors for testicular cancer. Int J Oncol 1998;13:1299-303.

34. Mills PK, Newell GR, Johnson DE. Testicular cancer associated with employment in agriculture and oil and natural gas extraction. Lancet 1984;1:207-10

35. Wiklund K, Dich J, Holm LE, et al. Risk of cancer in pesticide applicators in Swedish agriculture. Br J Ind Med 1989;46:809-14

36. Kristensen $P$, Andersen A, Irgens LM, et al. Cancer in offspring of parents engaged in agricultural activities in Norway: incidence and risk factors in the farm environment. Int J Cancer 1996; 65:39-50.

37. Moller $\mathrm{H}$. Work in agriculture, childhood residence, nitrate exposure, and testicular cancer risk: a case-control study in Denmark. Cancer Epidemiol Biomarkers Prev 1997;6:141-4.

38. Lynge E, Thygesen L. Occupational cancer in Denmark. Cancer incidence in the 1970 census population. Scand J Work Environ Health 1990;16(Suppl 2):3-35.

39. Martikainen $P$, Valkonen $T$. Bias related to the exclusion of the economically inactive in studies on social class differences in mortality. Int J Epidemiol 1999;28:899-904. 